\title{
UWARUNKOWANIA DOMINACJI I PODPORZĄDKOWANIA W GRUPACH DZIEWCZĄT I CHŁOPCÓW - WYCHOWANKÓW ZAKŁADÓW POPRAWCZYCH
}

\section{WSTEP}

Problem funkcjonowania młodzieży w instytucjach korekcyjnych od lat stanowi domenę głównie studiów z zakresu pedagogiki resocjalizacyjnej. Przedstawiciele tej dyscypliny nauk społecznych z reguły wyrażaja zainteresowanie problemem szeroko pojętego wychowania leżącego u podstaw oddziaływań resocjalizacyjnych. Powszechnie znane są koncepcje Czesława Czapówa i Stanisława Jedlewskiego, Lesława Pytki, Jana Szałańskiego, Adama Szecówki, Andrzeja Bałandynowicza, Wiesława Ambrozika, Marka Konopczyńskiego i wielu innych wybitnych przedstawicieli tej dyscypliny naukowej. Problem resocjalizacji i funkcjonowania instytucji korekcyjnych niejednokrotnie bywa także podejmowany przez praktyków, którzy z racji bogatych doświadczeń spisuja poczynione przez siebie obserwacje, wyrastające z pracy w jednostkach korekcyjnych. Przykładem moga być choćby prace Pawła Moczydłowskiego ${ }^{1}$, który stał na czele Centralnego Zarządu Zakładów Karnych (Drugie życie więzienia), czy praca Za murami poprawczaka Ryszarda Makowskiego ${ }^{2}$, byłego dyrektora Zakładu Poprawczego w Laskowcu.

Publikacje zarówno teoretyczne, jak i pisane przez praktyków poruszaja wiele różnych zagadnień $\mathrm{z}$ dziedziny prawa, zarządzania, pedagogiki czy psychologii i socjologii, sprawiają, że coraz więcej wiadomo na temat funkcjonowania instytucji, które Erving Goffman określił mianem totalnych. W opisach naukowych zdecydowanie przeważa nurt przyrodniczy, który opiera się na wykorzystaniu narzędzi ilościowych, w którym - jak pisze Beata Zięba-Kołodziej $^{3}-$,,interpretacja faktów ma charakter jednoznaczny, funkcyjny, przyczynowo-skutkowy". Autorka jednocześnie podkreśla konieczność badania realnej rzeczywistości, która w tego typu instytucjach zostaje odsłonięta za pomoca badań etnograficznych, monograficznych i wynikających z założeń

${ }^{1}$ P. Moczydłowski, Drugie życie więzienia, Oficyna Wydawnicza Łośgraf, Warszawa, 2002.

${ }^{2}$ R. Makowski, Za murami poprawczaka, Oficyna Wydawnicza Łośgraf, Warszawa, 2009.

${ }^{3}$ B. Zięba-Kołodziej, Jakościowe badanie instytucji $w$ pedagogice społecznej, w: T. Frąckowiak, K. Marzec-Holki i A. Radziewicza-Winnickiego (red.), Próby i szkice humanistyczne. Funkcje pedagogiki społecznej czasu teraźniejszego (mitu, wolności i mtodej demokracji), t. 4 (1), Wydawnictwo Naukowe Polskiego Towarzystwa Pedagogicznego, Poznań-Środa Wielkopolska 2010, s. 353-354. 
teorii ugruntowanej ${ }^{4}$, które zbiorczo określamy metodami jakościowymi. Metodologia teorii ugruntowanej jest mi szczególnie bliska, gdyż miałem okazję poznać jej specyfikę, prowadząc badania nad mobbingiem ${ }^{5}$. Także i w badaniach prowadzonych $\mathrm{w}$ zakładach poprawczych zdecydowałem się na zastosowanie teorii ugruntowanej w projektowaniu, gromadzeniu i analizie materiału empirycznego. Innym, zdecydowanie ważniejszym, argumentem za przyjęciem zarówno tej metodologii, jak i związanych z nią technik jakościowych jest sam temat badawczy, który koncentruje się na subtelnej i niełatwej do badania warstwie symbolicznej związanej $\mathrm{z}$ zachodzącymi procesami hierarchizacji, warunkującymi relacje między wychowankami. Ten kierunek poszukiwań w naturalny sposób pozwolił mi oprzeć się także na nurcie interpretatywnym, zwłaszcza zaś na założeniach symbolicznego interakcjonizmu. Wynikające z niego koncepcje dotyczące zarówno natury działań społecznych, wytwarzanych przez aktorów społecznych symboli w toku zachodzących interakcji, jak i sposobów ich definiowania i interpretowania sa niezwykle przydatne na etapie eksploracji i wyjaśniania badanych zjawisk. Symboliczny interakcjonizm, uporządkowany przez Herberta Blumera do postaci zwartej teorii, stwarza możliwość analizy i interpretacji gestów oraz działań aktorów społecznych skoncentrowanych wokół praktyk degradacyjnych i awansowych zachodzących w grupach wychowanków. Perspektywa interakcjonistyczna wydaje się także użyteczna ze względu na symboliczny charakter relacji (,,drugie życie”) wpisanych w „,nieformalną twarz” instytucji zamkniętej, jaka jest zakład poprawczy. Pozwala ona na osiągnięcie dużego stopnia wrażliwości na symboliczną otoczkę subtelnych gestów i działania składające się na grypserę, której elementami posługuje się pewna część wychowanków (tzw. zasadowcy).

\section{PERSPEKTYWA TEORETYCZNA}

Jak już wspomniałem wcześniej, w opisie interesujących mnie zjawisk zachodzących w grupach wychowanków zakładów poprawczych postanowiłem posłużyć się perspektywą interpretatywną, która w moim przekonaniu pozwala na uzyskanie pożądanego stopnia wrażliwości na procesy i działania będące przedmiotem badań. W kontekście prowadzonych tutaj analiz należy także wskazać na proponowana przez Herberta Blumera koncepcję działania i interakcji społecznej, stanowiącej przedmiot niniejszych badań. Zdaniem Blumera znaczenia rzeczy pochodza z interakcji społecznych. Zrozumienie czyjejś interpretacji rzeczywistości oznacza zagłębienie się w jej szeroko pojętym działaniu, z uwzględnieniem ,,zróżnicowanych, zakorzenionych biograficznie perspektyw poznawczych i pragmatycznych" ${ }^{6}$. Działaniem jednostka jest

\footnotetext{
${ }^{4}$ Ibidem, s. 354. M. Hammersley, P. Atkinson, Metody badań terenowych, tłum. S. Dymczyk, Wydawnictwo Zysk i S-ka, Poznań 2000.

${ }^{5}$ P. Chomczyński, Mobbing $w$ pracy $z$ perspektywy interakcyjnej. Proces stawania sie ofiara, Wydawnictwo Uniwersytetu Łódzkiego, Łódź 2008.

${ }^{6}$ A. Rokuszewska-Pawełek, Chaos i przymus. Trajektorie wojenne Polaków - analiza biograficzna, Wydawnictwo Uniwersytetu Łódzkiego, Łódź 2002, s. 12.
} 
w stanie budować ,symboliczną tkankę”, którą posługuje się, definiując i interpretując siebie oraz innych. Blumer odnosi pojęcie symbolicznego interakcjonizmu do „osobliwej i wyróżniającej się charakterem interakcji, która ma miejsce pomiędzy istotami ludzkimi. Osobliwość związana jest z faktem, że jednostki ludzkie interpretuja albo »definiuja « wzajemnie podejmowane działania zamiast jedynie na nie reagować. Ich »odpowiedź« nie jest formułowana bezpośrednio w stosunku do wzajemnych działań, lecz zamiast tego bazuje na znaczeniu, jakie przywiązują do tych działań"7. Joseph R. Gusfield podkreśla, że Blumer traktuje symboliczny interakcjonizm jako określoną perspektywę teoretyczną służącą do badania życia grupowego i zachowania ${ }^{8}$. Według Blumera zachowanie człowieka powstaje w trakcie jego interakcji z otoczeniem. „Uczestnicy muszą kreować swoją własną linię zachowania poprzez nieustanną interpretację swoich wzajemnych zachowań"9. Blumer zwraca także uwagę na ważny dla nas proces wzajemnego dopasowywania się partnerów interakcyjnych. Osiagany jest on w wyniku dwóch subprocesów: definiowania i interpretowania ${ }^{10}$. Poprzez interakcje powstaja symbole, które podlegaja percepcji oraz warunkuja dalsze wzajemne interakcje. Dzięki podejściu interakcyjnemu można spojrzeć na grupę $\mathrm{z}$ perspektywy relacji, jakie $\mathrm{w}$ niej zachodzą, i opisać ją także językiem owych relacji.

\section{ZAKŁAD POPRAWCZY JAKO INSTYTUCJA TOTALNA}

Zakład poprawczy, podobnie jak zakłady karne, w których osadzeni przebywają wbrew swojej woli, spełniaja przesłanki leżące u podstaw definicji i klasyfikacji instytucji totalnych zaproponowanych przez Ervinga Goffmana, w książce Asylums: Essays on the Social Situation of Mental Patients and Other Inmates (1961 r.). Goffman na trwałe wprowadził do słownika nauk społecznych termin instytucja totalna, którym i my się posługujemy w niniejszym artykule. Desygnatem tej nazwy przyjęło się za Goffmanem określać ,miejsce pobytu lub pracy większej liczby osób, które znajdują się w takiej samej sytuacji, pozostaja odcięte od szerszego społeczeństwa, wiodąc w zamknięciu przez określony czas formalnie administrowane życie"11. Także Amitai Etzioni podnosi problem przedmiotowego traktowania ludzi będących we władaniu instytucji totalnych, którzy są socjalizowani w kierunku kultury organizacyjnej panującej w tychże instytucjach, a także relacji autorytarnych pomiędzy kadrą kierowniczą a pracownikami w korporacjach ${ }^{12}$.

${ }^{7}$ H. Blumer, Symbolic Interactionism. Perspective and Method, Prentice-Hall, Inc. Englewood, New Jersey 1969, s. 78-79.

${ }^{8}$ J. R. Gusfield, A Journey with Symbolic Interactionism, „Symbolic Interaction” 26, 2003, nr 1, s. $119-139$, s. 121.

${ }^{9}$ H. Blumer, op. cit., 1969, s. 66.

${ }^{10}$ Ibidem, s. 66.

${ }^{11}$ E. Goffman, Asylums: Essays on the Social Situation of Mental Patients and Other Inmates, New York, Doubleday 1961, s. 11.

12 A. Etzioni, Authority, Structure and Organizational Effectiveness, „Administrative Science Quarterly" 4, 1959, nr 1, s. 43-67; por. także P. K. Manning, s.v. Total Institutions, w: Blackwell 
Bez zagłębiania się $\mathrm{w}$ opis funkcjonowania zakładu poprawczego pragnę nadmienić, że w zależności od typu placówki (zakład otwarty, półotwarty, zamknięty i o wzmożonym nadzorze wychowawczym) w mniejszym bądź większym stopniu wpisuje się ona w realia opisane przez Goffmana jako typowe dla instytucji totalnej. Charakteryzuje się ona tendencją do zawładnięcia czasem i zainteresowaniami swych członków, usiłuje przy tym wywierać wpływ na ich postawy i zachowania ${ }^{13}$. W tekście Goffmana Charakterystyka instytucji totalnych odnaleźć możemy podstawowe atrybuty, które składają się na ten typ organizacji:

- podporządkowanie wszelkich aspektów życia osób w nich umieszczonych jednolitej władzy zwierzchniej, odseparowanej od nadzorowanych w sposób formalny;

- każda aktywność członków odbywa się w towarzystwie pozostałych, którzy są traktowani przez personel jednakowo i wykonuja podobne czynności, te zaś są nadzorowane, zaplanowane i przymusowe. Zakończenie jednego etapu powoduje przejście do kolejnego;

- aktywność członków wynika ze szczegółowego planu, który koresponduje $\mathrm{z}$ celami instytucji;

- zatajeniu ulegaja informacje na temat poszczególnych członków;

- praca osób nadzorujących $\mathrm{w}$ ramach instytucji totalnej ma wymiar całodobowy;

- instytucja wytwarza symboliczne i fizyczne bariery odgradzające ja od społeczeństwa „na zewnątrz" ${ }^{14}$.

Realia funkcjonowania zakładów poprawczych wpisują ten rodzaj organizacji $\mathrm{w}$ desygnat nazwy instytucja totalna, która choć pozostaje pewnym typem idealnym, to jednak dobrze oddaje charakter omawianych tutaj zagadnień. W wypadku niniejszych badań zakres praw i obowiązków (np. wyjścia na przepustki, udział w zajęciach kulturalno-sportowych itd.) jest silnie uzależniony od oceny postawy wychowanka. Może się zatem okazać, że dla jednych placówka będzie w większym stopniu posiadała znamiona totalnej niż dla innych, w zależności od stopnia respektowania wewnętrznych uregulowań.

\section{METODOLOGIA BADAŃ NAD ZJAWISKIEM DOMINACJI I PODPORZĄDKOWANIA}

Przyjęcie określonej metodologii badań zawsze powinno stanowić konsekwencję analizy zarówno przedmiotu badań, jak i samej sytuacji badawczej. $\mathrm{W}$ badaniach instytucji totalnych należy przyjąć, że niejako same chronią one

\footnotetext{
Encyclopedia of Sociology Online, wyd. George Ritzer, 2007 (http://www.sociologyencyclopedia.com/ public/tocnode?id=g9781405124331_yr2011_chunk_g978140512433126_ss1-55 (dostęp: 28.06.2011).

${ }^{13}$ Por. A. Baranowska, Proces kształtowania się tożsamości $w$ instytucji totalnej na przyktadzie żotnierzy mieszkańców obozu Babilon w Iraku, Acta Universitatis Wratislaviensis, No. 3096, Sociologia XLV, Wrocław 2009, s. 21-30 i 22.

${ }^{14}$ E. Goffman, Charakterystyka instytucji totalnych, w: W. Derczyński, A. Jasińska-Kania, J. Szacki (red.), Elementy teorii socjologicznych, PWN, Warszawa 1975, s. 150-151.
} 
swoje tajemnice, co trafnie oddaje tytuł jednego z rozdziałów -Zastrzeżony teren badań - przywołanej wyżej pracy Moczydłowskiego ${ }^{15}$. Podobne trudności związane z dotarciem do miarodajnych badań w instytucjach zamkniętych opisuje Marek Kamiński w książce Gry więzienne. Tragikomiczny świat polskiego więzienia ${ }^{16}$. Uwagi te skłaniaja nas do konstatacji, że kluczowym problemem $\mathrm{w}$ opisywaniu zjawisk zachodzących $\mathrm{w}$ instytucjach totalnych jest problem niechęci badanych do ujawniania ich rzeczywistych poglądów oraz motywów działań. U podstaw motywów tych działań można wymienić: obawy przed ujawnieniem określonych zjawisk o charakterze pejoratywnym, niechęć rozmowy na temat tabu, brak zaufania do badaczy ze strony badanych, wstyd związany z aktualną sytuacja życiową, obawa braku zrozumienia, chęć wymknięcia się ocenie badacza, postrzeganie badacza jako osoby powiązanej $\mathrm{z}$ administracja placówki lub aparatem ścigania i wiele innych ${ }^{17}$. Ponadto niejednokrotnie barierę stanowią także kompetencje lingwistyczne i percepcyjne badanych, którzy często mają niskie wykształcenie. Biorąc pod uwagę te fakty, najbardziej odpowiednie wydają się techniki zapewniające jak najdłuższy kontakt badacza $\mathrm{z}$ badanymi, czego rezultatem jest większe zaufanie stwarzające możliwość ,„przedarcia się” przez deklarowaną warstwę wypowiedzi typowa dla technik opartych na krótkotrwałym kontakcie. W tym wypadku zastosowanie znalazły techniki obserwacji quasi-uczestniczacej jawnej oraz wywiadu swobodnego. Oba te narzędzia dają badaczowi możliwość śledzenia przez dłuższy czas interakcji w badanym środowisku, jak również pozwalają na wykrycie uwarunkowań, które faktycznie leżą u podstaw działań indywidualnych i zbiorowych ${ }^{18}$. Do badań wykorzystano także materiały wizualne $\mathrm{w}$ postaci materiału filmowego $\mathrm{z}$ kamer zainstalowanych $\mathrm{w}$ badanych instytucjach. Analiza tego typu danych była przeprowadzana niejednokrotnie przy pomocy personelu placówek, który wyjaśniał autorowi naturę interakcji i działań podejmowanych przez wychowanków, a także pozwolił na konsultowanie na bieżąco wniosków dotyczących wizualnych przejawów socjometrii grupowej.

Zaprezentowane w tym artykule badania opieraja się na 31 wywiadach swobodnych przeprowadzonych z personelem zakładów poprawczych oraz na 17 wywiadach swobodnych $\mathrm{z}$ wychowankami badanych instytucji. Gromadząc materiał empiryczny, autor korzystał z techniki obserwacji quasi-uczestniczącej, dlatego też spędził łącznie trzy miesiące we wszystkich wymienionych zakładach poprawczych. W tym czasie przebywał wśród wychowanków zakładowych $\mathrm{w}$ szkole, $\mathrm{w}$ czasie nauki zawodu $\mathrm{w}$ ramach warsztatów, w trakcie spożywania posiłków na stołówce, jak również w internacie w czasie wolnym od

15 P. Moczydłowski, op. cit. (zob. przyp. 1).

${ }^{16}$ Oficyna Naukowa, Warszawa 2006.

${ }_{17}$ Niniejsze obawy leżące $\mathrm{u}$ podstaw niechęci wobec badacza napotkałem podczas moich indywidualnych i grupowych rozmów przeprowadzonych z osobami osadzonymi w placówkach zamkniętych (zakłady poprawcze oraz zakłady karne). Wymienione motywy oczywiście nie wyczerpują całego wachlarza możliwości.

${ }_{18}$ M. Hammersley, P. Atkinson, Metody badań terenowych, tłum. S. Dymczyk, Wydawnictwo Zysk i S-ka, Poznań 2000, s. 16-17. 
zajęć dydaktycznych. Zgromadzony w ten sposób materiał empiryczny stwarza możliwość wyciągnięcia bardziej ogólnych wniosków, które pomimo braku statystycznej reprezentatywności próby badawczej, mogą się odnosić do wymienionych typów zakładów poprawczych.

\section{WYZNACZNIKI STATUSU W GRUPIE WŚRÓD DZIEWCZĄT I CHEOPCÓW}

Zarówno wśród dziewcząt, jak i chłopców wyróżnić można zbiór pewnych czynników, które stanowią warunki osiągania określonego statusu w grupie. Czynniki te $\mathrm{w}$ niektórych obszarach sa różne w wypadku obydwu płci, $\mathrm{w}$ związku z tym tam, gdzie jest to zasadne, istotny jest podział na grupy żeńskie i męskie. Warto także nadmienić, że grupowa percepcja układów hierarchicznych oraz stopień ich akceptacji zależą w dużej mierze od siły oddziaływania norm i zasad tzw. drugiego życia na członków grupy. Należy w tym momencie nadmienić, że „drugie życie” w zależności od zakładu poprawczego cieszy się różna popularnością wśród wychowanków i przyjmuje najczęściej postać zbioru arbitralnie wyselekcjonowanych wzorów postępowania niezbyt wiernie oddających dawną więzienną grypserę opisywaną przez Moczydłowkiego czy Kamińskiego. Sami wychowankowie nie do końca zdają sobie sprawę z pochodzenia i znaczenia określonych norm, poza tym stosuja je w sposób koniunkturalny, w zależności od tego, czy w danym momencie wiąże się to z czerpaniem korzyści z takiego zachowania. Nie wyklucza to jednak wpływu tzw. zasad na budowanie hierarchii w grupie, która mniej bądź bardziej oficjalnie przyznaje się do "grypsowania”. W związku z tym w zależności od relacji pomiędzy grupami „grypserów” a „niegrypsujących” może zdarzyć się taka sytuacja, w której każda $\mathrm{z}$ tych dwóch grup posiada zarówno inną hierarchię, w ramach której dochodzi do wyboru liderów, jak i inne kryteria warunkujące ,awanse” i „degradacje”. Moim celem jest omówienie tych uwarunkowań leżących u podstaw hierarchii, które są związane z „drugim życiem".

Wyznaczniki nieformalnego statusu osiaganego przez wychowanka moga być pochodną zarówno jego działań podjętych poza zakładem, w którym obecnie przebywa (pozycja osiagnięta $\mathrm{w}$ poprzednim zakładzie, zachowanie podczas rozprawy sądowej), jak i w samym zakładzie (oddziaływania na innych wychowanków, postawa wobec kadry). Ponadto wyznaczniki statusu moga wiązać się z atrybutami przypisanymi (wiek, wzrost, wygląd) lub osiagganymi (zachowanie, siła fizyczna, budowanie wizerunku atrakcyjnego dla pozostałych). Nie bez znaczenia wreszcie jest fakt, czy wychowanek wcześniej już przebywał $\mathrm{w}$ instytucjach opiekuńczych (inne zakłady poprawcze i schroniska dla nieletnich, domy dziecka, pogotowia opiekuńcze itd.) czy też trafia do zakładu poprawczego po raz pierwszy. W celu dokonania charakterystyki poszczególnych wyznaczników pozwolę sobie najpierw zaczać od tego, co jest wspólne dla grup chłopców i dziewcząt przebywających w zakładach. 


\section{Wyznaczniki pozycji $w$ hierarchii grup zakładowych wspólne dziewczętom i chłopcom}

\subsection{Przeszłość kryminalna}

Zarówno w wypadku dziewcząt, jak i chłopców, którzy deklarują w sposób mniej bądź bardziej otwarty ${ }^{19}$ udział w ,drugim życiu”, duże znaczenie ma przeszłość kryminalna wychowanka. Wbrew obiegowym opiniom nie jest tak, że im cięższe przestępstwo, tym większym poważaniem cieszy się jego sprawca. Raczej wyodrębnić można przestępstwa, które sprawiaja, że wychowanek zostaje wykluczony $\mathrm{z}$ grupy lub poważnie ograniczają się jego możliwości osiagnnięcia wysokiej pozycji w grupie, i jednocześnie skazuja wychowanka na posiadanie niepełnych praw w grupie lub też ich zupełne pozbawienie. Sa to przestępstwa oparte na agresji seksualnej w wypadku chłopców oraz świadczenie usług seksualnych - dziewcząt. Chłopcy, którzy dopuścili się przestępstw seksualnych, zwłaszcza wobec dzieci, osiagaja najniższą możliwą pozycję $\mathrm{w}$ zakładzie. Ich sytuacja różni się $\mathrm{w}$ zależności od tego, jak silna jest władza formalna w placówce, i w związku z tym, jaki jest stopień kontroli zachowań związanych z „drugim życiem”. Jeśli władza w zakładzie poprawczym faktycznie jest sprawowana przez ,grypsujacych”, to wychowanek jest przedmiotem agresji werbalnej i niewerbalnej (tzw. dojeżdżanie). Gdy zakład kontroluje sytuację, a działania związane z „drugim życiem” są konsekwentnie penalizowane, wychowanek doświadcza odrzucenia i marginalizacji ze strony grupy (np. poprzez odmowę wykonywania wspólnych czynności z takim wychowankiem). Na podobnych zasadach odrzucani są ci wychowankowie obydwu płci, którzy dopuścili się agresji wobec któregoś z członków rodziny, w szczególności matki ${ }^{20}$.

\subsection{Staż pobytu $w$ zakładzie}

Kolejnym ważnym czynnikiem, który decyduje o pozycji w zakładzie poprawczym, jest okres w nim spędzony. Zazwyczaj ci wychowankowie, którzy przebywają w danym zakładzie dłużej (kilka lat), mają dość wysoką pozycję czy też najwyższą. Pełnia oni rolę ,,gospodarzy”, dobrze zorientowanych $\mathrm{w}$ formalnych, a jeszcze lepiej - nieformalnych aspektach funkcjonowania w placówce. Ich wiedza stanowi pewien kapitał, który przynosi wymierne korzyści w postaci działań zwiększających szanse powodzenia określonych przedsięwzięć, takich jak uzyskanie przywilejów dla grupy (np. możliwość „wspólnego palenia" papierosów poza przewidzianym kalendarzem, wydłużenie czasu przeznaczonego na grę lub oglądanie filmów itd.). Staż pobytu wiąże się z posiadaniem pewnego rodzaju mapy postępowania. „Starzy”

19 Tutaj zauważyć można pewną prawidłowość, mianowicie: ci, którzy faktycznie wyznają zasady drugiego życia, z reguły nie decydują się na rozmowy z badaczem i traktują go jako ,element wrogi” lub też wypierają się uczestnictwa w ,drugim życiu”.

${ }^{20}$ Matka jest w podkulturze więziennej, na której niejednokrotnie wzorują się wychowankowie, przedmiotem najwyższego szacunku i wyrazem najszczerszych uczuć. Niejednokrotnie więźniowie tatuują motyw matki na swoim ciele (por. Moczydłowski, ibidem). 
wychowankowie w przeciwieństwie do „,świeżaków” wiedzą, z którym pracownikiem, w jaki sposób i w jakich okolicznościach można coś ,,ugrać”, czyli uzyskać pozwolenie, uwarunkowane posiadanym zaufaniem, na wykonywanie pewnych czynności niedostępnych „nowym” (np. przedłużenie czasu wolnego, oddalenie się bez dozoru celem uzyskania pozwolenia na aktywność sportowa grupy itd.). Bardziej doświadczeni wychowankowie doskonale orientują się także w infrastrukturze budynku placówki, co daje im możliwość ukrycia niedozwolonych zachowań bezpośrednio przed pracownikiem lub przed kamerami monitoringu. W związku z tym rzadko zdarza im się tzw. przypał, czyli wpadka. Na podstawie powyższych obserwacji można stwierdzić, że przebywanie $\mathrm{w}$ gronie doświadczonych wychowanków wiąże się z korzyściami dla tych, którzy takiego doświadczenia nie maja. W tym celu akceptują oni określone wzory zachowań wymagane przez doświadczonych wychowanków.

\subsection{Kompetencje osobowościowe}

Podobnie jak w literaturze przedmiotu dotyczącej przywództwa nie udało się jasno określić w ramach teorii atrybutywnych zestawu cech, jakie posiadać powinien lider ${ }^{21}$, tak i w wypadku badań próba taka nie może się zakończyć sukcesem. Zamiast tego łatwiej jest wskazać, jakie cechy eliminuja możliwość zajęcia wysokiej pozycji $\mathrm{w}$ grupie. Z pewnością wychowankowie lękliwi, zewnątrzsterowni, niepewni swego zdania nie maja szans na zdobycie i utrzymanie wysokiego statusu. Ten zarezerwowany jest dla tych, których osobowość jest atrakcyjna dla pozostałych, czyli oceniana jako zdecydowana, twarda, niepoddająca się naciskom, a przez to zbieżna $\mathrm{z}$ szeroko propagowanym kultem siły fizycznej i psychicznej. Także ci wychowankowie, którzy nie posiadają wystarczających kompetencji interakcyjnych, czyli śmiałości w kontaktach z innymi, towarzyskości ujawnianej podczas wykonywania wspólnych obowiązków, mają mniejsze szanse na uzyskanie wysokiego statusu w grupie. Warto także nadmienić, że ci, których działania ukierunkowane na przekonanie innych, że posiadaja bardziej atrakcyjną osobowość niż faktyczna, zakończa się porażka, zazwyczaj zajmuja niższe pozycje w grupie niż ci, którzy od samego początku prezentowali osobowość mniej atrakcyjną, lecz „własną". We wszystkich zakładach poprawczych, w których do tej pory realizowałem badania, prawidłowość ta zawsze była prawdziwa. Najczęściej nieudana próba przekonania innych do osobowości bardziej atrakcyjnej dla grupy niż ta, którą się faktycznie posiada, była udziałem wychowanków „,nowych” zarówno w zakładzie, jak i ze względu na brak wcześniejszych doświadczeń z placówkami zamkniętymi. Strategia ta realizowana była z kilku powodów: ze strachu przed zajęciem pozycji najniższej, z chęci zajęcia pozycji wysokiej na starcie, w ramach działań prewencyjnych majacych ochronić daną osobę przed spodziewaną agresją ze strony pozostałych itd.

\footnotetext{
${ }^{21}$ Por. S. P. Robbins, Zachowania w organizacji, PWE, Warszawa 1998; P. Chomczyński, Style przywódcze kierowników polskich firm produkcyjnych, w: J. S. Banaszak, K. Doktór, Socjologiczne, pedagogiczne i psychologiczne problemy organizacji i zarzadzania, Wyd. WSKiZ, Poznań 2009.
} 


\subsection{Skłonność do działań ryzykownych}

Osobowość człowieka postrzegana jest przez pozostałych przez pryzmat jego działań. W warunkach instytucji totalnej, jaka bez wątpienia jest zakład poprawczy, twierdzenie to nabiera szczególnego znaczenia. Zarówno wśród dziewcząt, jak i chłopców walka o pozycję w grupie, a także działania na rzecz jej utrzymania charakteryzują się podejmowaniem zachowań ryzykownych. W pierwszym wypadku, tj. wtedy gdy działania są ukierunkowane na zdobycie wyższej pozycji w hierarchii grupowej, maja one charakter ofensywny skierowanej najczęściej wobec innych wychowanków, rzadziej kadry. Walczący o „renomę” niejednokrotnie są agresywni i nieobliczalni. Te dwa elementy stanowią o ich antycypowanej atrakcyjności dla grupy, która ceni sobie siłę fizyczną i psychiczną, a także odwagę.

Inne motywy leżą u podstaw inicjowania działań ryzykownych w wypadku tych wychowanków, którzy walczą o utrzymanie dotychczasowej pozycji. Ci zobowiązani są przez grupę do określonej reakcji w razie wystąpienia warunków koniecznych do podjęcia ataku/obrony. Jednym z takich warunków jest naruszenie zasad przez innego wychowanka (np. ubliżanie rodzinie wychowanka, solidarna obrona innego wychowanka) lub przez kadrę (np. niesłusznie wymierzona kara). Okoliczności te niejako usprawiedliwiają, a także zmuszaja wychowanka do aktywności, gdyż w braku jej wystąpienia grupa może negatywnie ocenić respektowanie zasad, co stanowi warunek sine qua non zajmowania wysokiej pozycji w hierarchii.

\section{Wyznaczniki pozycji w hierarchii grup zakładowych różne w wypadku dziewcząt i chłopców}

Jak już nadmieniłem wcześniej, istnieją wspólne dziewczętom i chłopcom i różne dla nich uwarunkowania i wyznaczniki leżące u podstaw osiagania pozycji w grupie. W tym miejscu chcę omówić różnice, jakie się pojawiaja w środowisku żeńskim i męskim.

\subsection{Zachowania homoseksualne}

Zachowania homoseksualne wyraźnie różnicują środowisko dziewcząt i chłopców w zakresie zajmowania określonego statusu w hierarchii grupowej. Wśród dziewcząt zauważyć można, że zazwyczaj te, które przyjmuja „rolę męską" (,dziewczęta męskie” ${ }^{22}$ zarówno na poziomie zachowań (zachowanie typowe dla chłopców, czyli np. poklepywanie dziewcząt po pośladkach, przytulanie, inicjowanie zbliżeń), jak i sposobu ubierania się i stylizacji typowej dla chłopców (krótko obcięte włosy i paznokcie, brak makijażu, typowo męski sposób poruszania się itd.), zazwyczaj osiagają wysoka pozycję w grupie. Relacje pomiędzy tymi dziewczętami a pozostałymi niejednokrotnie przypominaja

${ }^{22}$ Dla uporządkowania wywodu pozwolę sobie na zastosowanie pewnych określeń na dziewczęta, które przyjmują rolę męską, i te, które zachowują rolę kobiecą. Te pierwsze zdecydowałem się nazwać „,dziewczęta męskie”, te drugie zaś - „,dziewczęta kobiece”. 
relacje damsko-męskie także w zakresie rywalizacji, dominacji i podporządkowania. Dziewczęta męskie sa niejednokrotnie obiektem zazdrości i adoracji w sposób przypominający adorowanie chłopców przez dziewczęta w klasach szkolnych silnie sfeminizowanych. Okazywanie sympatii „kobiecej dziewczynie" przez dziewczęta spełniające rolę chłopców niejednokrotnie wywołuje zazdrość u pozostałych kobiecych dziewcząt, których działania zmierzaja w kierunku ,odbicia chłopaka”. Przyjmuje to niejednokrotnie formę kokietowania (głaskanie po twarzy, zalotne spojrzenia, uwodzacy ton głosu itd.). O prawdziwości tych obserwacji przekonałem się także wtedy, gdy stałem się sam przedmiotem agresji słownej i niechęci okazywanej przez męskie dziewczęta w momencie, gdy po raz pierwszy pojawiłem się z placówce żeńskiej. Miałem wrażenie, że dziewczęta te potraktowały mnie jako „,konkurenta”. Moje przypuszczenia poddałem weryfikacji $\mathrm{w}$ trakcie rozmów $\mathrm{z}$ wychowawcami i samymi wychowankami. Okazały się one słuszne, dlatego musiałem dołożyć jeszcze większych starań, by moje zachowanie nie było w żadnym wypadku odbierane jako chęć nawiązania bliższego kontaktu.

Dokładnie przeciwne tendencje zaobserwować można w grupach chłopców przebywających w zakładach poprawczych. W trakcie moich badań nie spotkałem się z zachowaniami homoseksualnymi przejawianymi przez wychowanków także dlatego, że są one silnie napiętnowane. Już na poziomie języka stwierdzić można, że osoby homoseksualne podlegałyby procesom degradacji i odrzucenia. Nazwanie kogoś określeniem związanym ze świadczeniem usług homoseksualnych (np. ciota, dziwka itd.) traktowane jest jako wyjątkowo obraźliwe i niejednokrotnie jest powodem agresji.

Motyw zachowań seksualnych pojawił się kilkukrotnie w trakcie rozmów $\mathrm{z}$ wychowankami i personelem na temat zajmowania pozycji $\mathrm{w}$ hierarchii grupowej. Badani wskazali, że homoseksualizm wśród chłopców ma dwa oblicza, każde z nich zaś wiąże się z odmiennymi konsekwencjami w zakresie zajmowanego statusu w grupie. Ci chłopcy, którzy świadczą usługi homoseksualne $\mathrm{w}$ zamian za określone dobra (np. papierosy), przywileje (nietykalność fizyczna, ochrona przed agresją) mają najniższy możliwy status i nie mają szansy na jego zmianę bez względu na to, jakie motywy leżały u podstaw ich decyzji. Osobom tym nadawany jest status ,żeński”, co jednocześnie wyklucza je z grona „mężczyzn” i wykonywania przez nich męskich czynności (np. odmowa udziału w sportowych grach zespołowych). Odmienna sytuacja pojawia się w wypadku tych wychowanków, którzy dopuszczają się praktyk homoseksualnych, lecz zachowuja pozycję aktywną, traktowaną jako męską. Ci chłopcy nie podlegają stygmatyzacji, gdyż poprzez swoją dominację, w tym wypadku seksualną, nadal zachowują „,rolę męską”, a ich „męskość” nie jest kwestionowana przez pozostałych. U podstaw tego mechanizmu leży implicite wyrażane przekonanie, że praktyki te sa spowodowane warunkami odosobnienia i brakiem dostępu do kobiet, co rodzi potrzebę substytucji. Wychowankowie przyjmuja, że w warunkach ,wolnościowych” praktyki seksualne zyskałyby charakter heteroseksualnych $\mathrm{w}$ sposób automatyczny. Ponadto wyraźnie daje się w tym wypadku odczuć wpływ ideologii więziennej, który jest dość silny z racji powiązań rodzinnych wychowanków z ich krewnymi, którzy 
niejednokrotnie odsiadują karę pozbawienia wolności. Normy więzienne szczegółowo precyzuja status relacji homoseksualnych oraz ich stron, a w związku $\mathrm{z}$ tym także ich miejsce $\mathrm{w}$ grupie.

\subsection{Udział w konflikcie}

Środowisko dziewcząt i chłopców zdecydowanie różni się ze względu na relację pomiędzy formą udziału w konflikcie a statusem $\mathrm{w}$ grupie. Wśród dziewcząt daje się odczuć o wiele większa dowolność w zakresie działań agresywnych przejawianych w razie konfliktu. Dziewczęta podejmują się działań zarówno bezpośrednich (np. walka, plucie), jak i pośrednich (np. oddawanie moczu do szamponu przeciwniczki pod jej nieobecność), lecz żadne z nich nie powoduje degradacji statusu agresorki, niekiedy zaś darzona jest ona większym respektem jako osoba bezwzględna, z która , nie warto zaczynać”. Ponadto dziewczęta znacznie rzadziej występują w konflikcie w sposób otwarty, wybierają raczej działania zakulisowe i skryte (np. budowanie koalicji wymierzonej przeciwko konkurentce za jej plecami), jednocześnie na zewnątrz stwarzaja pozory braku aktywności. W tym wypadku miara powodzenia jest końcowy wynik sporu, nie zaś forma, w jakiej on przebiega. Realizuje się tutaj zasada: ,cel uświęca środki”.

Wśród chłopców daje się wyraźnie zauważyć występowanie określonych reguł, które porządkują przebieg konfliktu i czynią go bardziej przewidywalnym, a których nieprzestrzeganie może wiązać się z utrata dotychczas zajmowanej pozycji w ramach hierarchii grupowej. Wysoka pozycję zdobywaja lub utrzymują już zdobytą ci, którzy działają w sposób otwarty i odważny. Chłopiec o ,,́redniej” pozycji może ,,awansować”, gdy np. odpowie atakiem na zaczepki wychowanka o wyższej pozycji, choć szansa wygranej jest niewielka. Grupa nagradza jednak odwagę utożsamianą z „męskością, wpisującą się w kult siły zarówno fizycznej, jak i charakteru. Jednocześnie ci wychowankowie, którzy „nie grają fair” (np. poprzez inicjowanie działań zakulisowych, traktowanych jako działanie typowe dla dziewczą), zajmują zazwyczaj niższe pozycje, bez względu na wynik sporu. Można w tym wypadku mówić o pyrrusowym zwycięstwie - choć przeciwnik został pokonany, to jednak w percepcji grupowej status zwycięzcy został nadszarpnięty.

\subsection{Relacje z personelem}

Relacje z personelem także różnią się $\mathrm{w}$ środowisku dziewcząt i chłopców. Wśród tych ostatnich zasadą ogólną jest brak okazywania sympatii do kadry. Chłopcy raczej traktuja kadrę na dystans bez względu na to, jak popularny i lubiany jest dany wychowawca, kierownik, dyrektor lub strażnik. Ci, którzy podchodzą bardzo restrykcyjnie do reguł „drugiego życia”, starają się także przybierać jawnie wroga postawę, np. poprzez nierespektowanie poleceń, ośmieszanie, stosowanie wulgarnego języka itd. (zob. wyżej). Wyjątek stanowić moga te zachowania, które są wyraźniej ukierunkowane na osiągnięcie określonego celu i tak też są postrzegane przez grupę. Działania o podłożu instrumentalnym 
i przybierające formę zachowań uległych są przez pozostałych „,rozgrzeszane” ze względu na ,,cel wyższy” leżący u ich podstaw. Świadczą one o sprycie i przebiegłości, a także umiejętności wprowadzania w błąd pracowników, co czyni z nich „frajerów” w oczach chłopców, inicjatora tej strategii zaś - wygranym. Wygrana jest tym większa, im grupa odnosi większe korzyści z podjętych działań i ich rezultatów. „Zwycięzca” niejednokrotnie przypieczętowuje swój sukces, a zarazem symbolicznie odcina się od swojego instrumentalnego zachowania, epitetem pod adresem oszukanego pracownika. Innym wyjątkiem są niekiedy relacje z psychologiem, pedagogiem lub też innym pracownikiem spełniającym taką funkcję. Te niejednokrotnie są szczere i emocjonalne, lecz jedynie w kontakcie bezpośrednim bez udziału innych wychowanków. Gabinet psychologa niejednokrotnie stanowi swoiste „,sacrum”, w którym wychowanek może zrzucić maskę, zdobyć się na szczerość wypowiedzi i zachowań, w tym okazywanie prawdziwych emocji (duma, wstyd, radość, smutek itd.). Podstawą tej relacji opartej na szczerości jest zachowanie tajemnicy przez psychologa lub pedagoga i nieokazywanie bliskich relacji z wychowankiem w obecności innych.

W wypadku dziewcząt relacje pomiędzy wychowankami a kadrą nie sa objęte tak restrykcyjnymi regułami i w większym stopniu opieraja się na emocjach. Dziewczęta dopuszczaja możliwość utrzymywania bliskich relacji emocjonalnych $\mathrm{z}$ kadra, $\mathrm{z}$ tym że relacje te różne są w stosunku do mężczyzn i do kobiet pracujących w placówce. Ci pierwsi sa postrzegani dwojako, z jednej strony jako obiekty seksualne (w tym wypadku dziewczęta starają się kusić i uwodzić swój obiekt pożądania, prawie zawsze doznają porażki i przerzucaja swoje uczucia na inny obiekt), z drugiej zaś - jako autorytet ojcowski (dziewczęta zwierzaja się, zasięgaja opinii w kwestii swojego zachowania, ubioru itd.). W tej drugiej sytuacji niejednokrotnie skłonne są wysłuchać uwag krytycznych pod swoim adresem i je zaakceptować, co nie jest możliwe w pierwszej. Obie te relacje niekiedy przybieraja postać bliskości fizycznej inicjowanej przez dziewczęta, które starają się usiąść na kolanach wychowawcy, przytulić się itd. W sytuacjach pierwszego rodzaju wychowawcy zazwyczaj wyznaczaja granicę okazywania sympatii, w drugiego zaś - zezwalają na tę formę bliskości, gdyż ma ona w ich przekonaniu charakter resocjalizacyjny i jest bezpieczna, także dla wychowawcy. Ten ostatni niejednokrotnie spełnia w odczuciu wychowanek rolę ojca, którego te nigdy nie miały lub z którym kontakt utraciły albo miał on charakter negatywny. Ta ostatnia relacja typu ojcowskiego znajduje także swój odpowiednik w relacjach dziewcząt z żeńskim personelem. Wychowawczynie niejednokrotnie sa traktowane jako przyjaciółki, a nawet matki. Wielokrotnie powierza się im sekrety, pyta je o radę, także w kwestiach intymnych. Relacje te nacechowane są także fizyczną bliskością i czułością eksponowaną przez obydwie strony. Można jednak zauważyć, że grupa dziewcząt określa, z kim można się spoufalać, a z kim nie, wychowanki zaś sa zobowiązane do przestrzegania tych zasad. Niedostosowanie się do tych reguł (np. okazywanie sympatii nielubianemu pracownikowi lub takiemu, który w chwili obecnej jest w konflikcie z grupa) może grozić wykluczeniem i ostracyzmem. Najczęściej przyjmuje on formę ośmieszania, oskarżeń o donoszenie oraz brak lojalności wobec grupy. 


\section{ZAKOŃCZENIE}

Problem uwarunkowań leżących u podstaw zajmowania określonej pozycji przez wychowanków w zakładach poprawczych jest niezwykle złożony. Prezentacja wniosków w tym wypadku związana jest $\mathrm{z}$ pewnymi uproszczeniami i selekcją podnoszonych wątków, gdyż rozmiar artykułu sprawia, że nie wszystkie moga być zaprezentowane. Niemniej daje się zauważyć pewne zjawiska, które występuja powszechnie we wszystkich odwiedzonych przeze mnie placówkach. Te, które zostały w tym miejscu opisane, sa jednocześnie najbardziej widoczne i także najbardziej powszechne. Dały się one zarówno zauważyć „naocznie” w ramach prowadzonej przeze mnie obserwacji quasi-uczestniczącej jawnej, zostały również potwierdzone w toku dalszych rozmów mniej lub bardziej formalnych zarówno z wychowankami, jak i personelem.

Charakter instytucji, w których prowadzono badania, skłania do pewnych konstatacji, wynikających również z przebiegu opisanych wcześniej mechanizmów. Zjawiska przedstawione $\mathrm{w}$ niniejszym artykule $\mathrm{w}$ mniejszym lub większym stopniu występują także w innych instytucjach o charakterze otwartym (np. szkoły), lecz stopień ich nasilenia jest mniejszy. U podstaw tej zależności leży sama natura instytucji totalnej, w której nie istnieje swoboda zachowań ani nie można uniknąć określonych sytuacji, zmienić środowiska, uzyskać pomocy z zewnątrz - wymusza to bardziej intensywne działania mające na celu uzyskanie zamierzonego efektu. Zamknięta przestrzeń, rutyna i powtarzalność porządku dnia, a także perspektywa dłuższego pobytu, czyli warunki typowe dla instytucji totalnej, wymuszaja intensyfikację interakcji i podjęcie określonych działań, które maja charakter porządkujący rzeczywistość zakładową.

Należy także nadmienić, że prowadzenie przedstawionych badań i pozyskiwanie materiału empirycznego opieraja się na budowaniu i utrzymywaniu zaufania ze strony zarówno wychowanków, jak i personelu. Niejednokrotnie weryfikacja pewnych przypuszczeń trwała bardzo długo, gdyż brakowało właśnie zaufania. Ten właśnie czynnik sprawia, że badania „,rzeczywistości broniącej się przed poznaniem" są czasochłonne i nie zawsze zakończone powodzeniem. Można jednak zasadnie przypuszczać, że metody jakościowe w większym stopniu niż inne dają możliwość dotarcia do tych jakże delikatnych procesów grupowych.

dr Piotr Chomczyński

Uniwersytet Łódzki

chomczynski@gmail.com 


\section{CONDITIONS FOR THE SHAPING OF DOMINATION AND SUBORDINATION IN GIRLS AND BOY GROUPS IN REFORMATORY INSTITUTIONS}

\section{Summary}

The main aim of this paper is to present the results of research focused on in-group processes among boys and girls located in four semi-open reformatories and one highly restricted facility. The problem of hierarchisation based on both processes of domination and subordination is presented. It characterises juveniles who declare being obedient to underground life principles. The paper also analyses the differences between mechanisms used by girls and boys aimed to maintain or change some hierarchical relations. 
Copyright of Journal of Law, Economics and Sociology is the property of Faculty of Law and Administration of Adam Mickiewicz University in Poznan and its content may not be copied or emailed to multiple sites or posted to a listserv without the copyright holder's express written permission. However, users may print, download, or email articles for individual use.

Właścicielem praw autorskich do „Ruchu Prawniczego, Ekonomicznego i Socjologicznego” jest Wydział Prawa i Administracji Uniwersytetu im. Adama Mickiewicza w Poznaniu. Zawartość czasopisma nie może być kopiowana, przesyłana do innych stron internetowych bądź zamieszczana na blogach bez pisemnej zgody wydawcy. Niemniej artykuły można drukować, kopiować lub przesyłać w formie elektronicznej na własny użytek. 